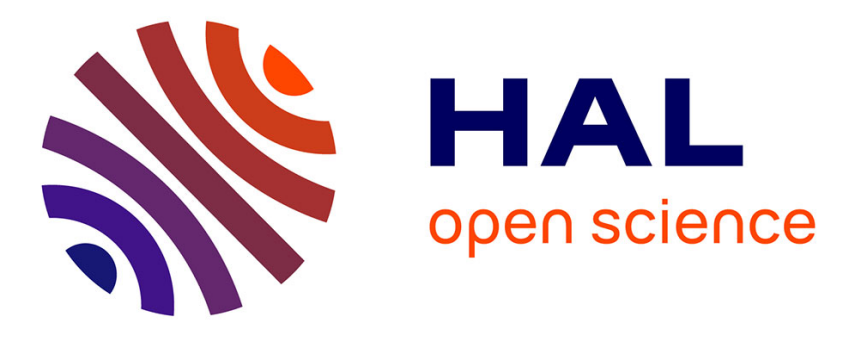

\title{
Mechanical harvest: a realistic challenge for processed apricot market?
}

\author{
Barbara Gouble, Patrice Reling, Catherine M.G.C. Renard, Jean-Marc \\ Broquaire, Christophe Chamet, Jean Marc Audergon
}

\section{To cite this version:}

Barbara Gouble, Patrice Reling, Catherine M.G.C. Renard, Jean-Marc Broquaire, Christophe Chamet, et al.. Mechanical harvest: a realistic challenge for processed apricot market?. 16. International Symposium on Apricot Breeding and Culture, Jun 2015, Shenyang, China. p. 38, 2015. hal-02794857

\section{HAL Id: hal-02794857 https://hal.inrae.fr/hal-02794857}

Submitted on 5 Jun 2020

HAL is a multi-disciplinary open access archive for the deposit and dissemination of scientific research documents, whether they are published or not. The documents may come from teaching and research institutions in France or abroad, or from public or private research centers.
L'archive ouverte pluridisciplinaire HAL, est destinée au dépôt et à la diffusion de documents scientifiques de niveau recherche, publiés ou non, émanant des établissements d'enseignement et de recherche français ou étrangers, des laboratoires publics ou privés. 
XVI International Symposium on Apricot Breeding and Culture and XV Chinese National Symposium on Plum and Apricot

\section{ABSTRACTS}
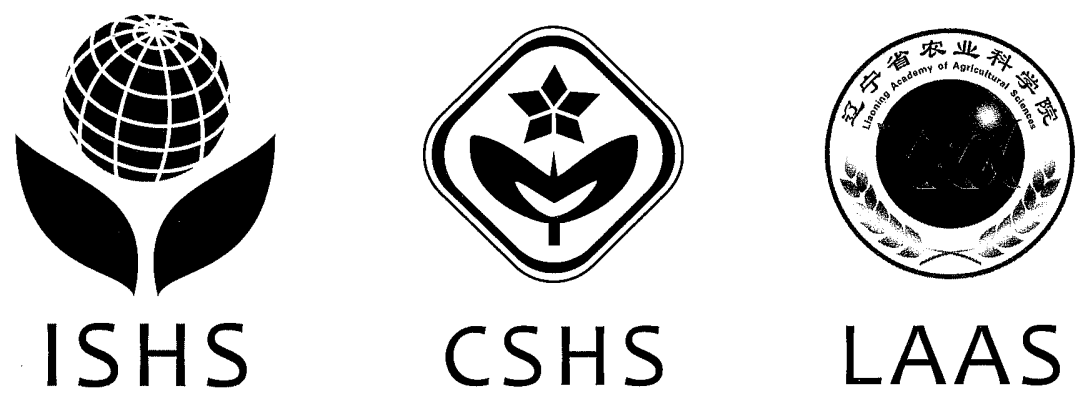

June 29-July 3, 2015, Shenyang, China

Edited by: Weisheng LIU, Shuo LIU, Xaioxue MA 


\title{
Mechanical Harvest: A Realistic Challenge for Processed Apricot Market?
}

Barbara GOUBLE ${ }^{1}$, Patrice RELING ${ }^{1}$ and Catherine M.G.C. RENARD ${ }^{1}$

INRA, UMR408 Sécurité et Qualité des

Produits d'Origine Végétale

F-84000 Avignon

France

Jean-Michel BROQUAIRE

sica CENTREX, F-66440 Torreilles

France

Jean-Marc AUDERGON

INRA, Unité de Génétique et

d'Amélioration des Fruits et Légumes,

F-84143 Montfavet

\author{
${ }^{1}$ Université d'Avignon et des Pays de \\ Vaucluse, UMR408 Sécurité et Qualité \\ des Produits d'Origine Végétale \\ F-84000 Avignon \\ France
}

Christophe CHAMET

SEFRA, F-26800 Etoile

France

France

Keywords: Quality, grading classes, dedicated orchard

\begin{abstract}
ILLIAD is a French national project in which sustainable food chain innovations were evaluated. One of the brakes in French apricot production is the high cost of manpower in this culture but also that fruit processors rely on the surplus fruits from the fresh consumption. This leads to a very high variability in supply, prices and quality from year to year. In this context, one solution might be a dedicated orchard to processing industries.

At first, varieties well adapted for processing and with a low demand of inputs, were screened for their behavior in mechanical harvest. Mechanical harvest was carried out using tree shaking (at $40 \mathrm{~cm}$ from the ground) and collection on a fabric screen. Results obtained during 2 years on more than 15 varieties and in 2 production areas are presented.

Low mechanical damages observed just after harvesting or after 7 days of storage for few varieties and the possibility to optimize shaking parameters according to agronomic and physiologic criteria (fruit falling, maturity heterogeneity,...) confirm the possibility of doing mechanical harvest and the opportunity to create dedicated orchards. Moreover, it seems possible to extend the mechanization process for apricot fresh market and not only for processed ones.
\end{abstract}

